Oral Section

\title{
Comparative study of two bioassays with weakened duckweed and yeast treated with homeopathic preparations
}

\author{
Tim Jäger ${ }^{1,2}$ *, Claudia Scherr ${ }^{1,3}$, Meinhard Simon ${ }^{4}$, Peter Heusser ${ }^{5}$, \\ Ursula Wolf1, and Stephan Baumgartner ${ }^{1,3,5}$ \\ 1Institute of Complementary Medicine KIKOM, University of Bern, Switzerland \\ 2Research Institute of Organic Agriculture, Frick, Switzerland \\ ${ }^{3}$ Society for Cancer Research, Hiscia Institute, Arlesheim, Switzerland \\ ${ }^{4}$ Inst. for Chemistry and Biology of the Marine Environment, Univ. Oldenburg, Germany \\ ${ }^{5}$ Center for Integrative Medicine, University of Witten/Herdecke, Germany
}

\begin{abstract}
Background: In homeopathic basic research, the question as to the most adequate test systems and apt methodology is still open.

Aims: This investigation examined the hypothesis that more complex organisms show stronger reactions to homeopathic remedies than less complex ones. We compared two Arsenic (As ${ }^{5+}$ ) stressed bioassays with duckweed (Lemna gibba, a multi-cellular autotrophic organism) and yeast (Saccharomyces cerevisiae, a singlecellular heterotrophic organism) regarding their response to homeopathic preparations [1].
\end{abstract}

Methods: For duckweed, growth rates of leaf area and leaf number were evaluated. For yeast, growth kinetics were determined by measuring slope, yield and Et50 (point in time when yield was half maximum) of the sigmoid growth curve. The experiments with duckweed and yeast were performed in parallel (same day, same location and identical homeopathic preparations).

Results: After screening 17 substances, three homeopathic preparations (Arsenicum album, nosode, gibberellic acid) were chosen for repeated experimental series [2]. Five independent experiments were conducted for each remedy with both organisms in parallel. Potency levels used were in the range of $17 \mathrm{x}-33 \mathrm{x}$ for duckweed and $17 \mathrm{x}-30 \mathrm{x}$ for yeast. To control for test system stability, systematic negative control experiments were conducted over the complete experimentation period. All experiments were blinded and randomized. The systematic negative control experiments did not yield any significant effects. Application of potentized Arsenicum album in the duckweed bioassay yielded the largest effects compared to water controls without remedies for the parameters leaf area and leaf number $(\mathrm{p}<0.001)$ [1, 3]. Potentized nosode preparations also had significant effects on duckweed's leaf area and leaf number $(\mathrm{p}<0.01)$. Growth was enhanced across all potency levels. In the yeast system the three homeopathic remedies did not show any significant effects on any growth curve parameter.

Conclusions: The results obtained are in line with the hypothesis, that more complex organisms show stronger reactions to homeopathic remedies than less complex organisms. The test system with Lemna gibba, 
the stressor arsenic $\left(\mathrm{As}^{5+}\right)$ and the homeopathic preparation Arsenicum album is suitable to further investigate factors influencing the quality and effects of potentized substances [4].

Keywords: homeopathy; duckweed; yeast; arsenic; Arsenicum album

\section{References:}

[1] Jäger T, Scherr C, Wolf U, Simon M, Heusser P, and Baumgartner S. Investigation of arsenic-stressed yeast (Saccharomyces cerevisiae) as a bioassay in homeopathic basic research. ScientificWorldJournal. 2011 March 7;11:568-583.

[2] Jäger T, Scherr C, Simon M, Heusser P, and Baumgartner S. Development of a test system for homeopathic preparations using impaired duckweed (Lemna gibba L.). J Altern Complement Med. 2011;17:315-323.

[3] Jäger T, Scherr C, Simon M, Heusser P, and Baumgartner S. Effects of homeopathic arsenicum album, nosode, and gibberellic acid preparations on the growth rate of arsenic-impaired duckweed (Lemna gibba L.). ScientificWorldJournal. 2010 November 4;10:2112-2129.

[4] Jäger T, Scherr C, Shah D, Majewsky V, Betti L, Trebbi G, et al. Use of homeopathic preparations in experimental studies with abiotically stressed plants. Homeopathy. 2011;100:275-287.

\section{(c)) BY-NC-ND Licensed to GIRI}

Support: This investigation was funded by Weleda AG (Arlesheim, Switzerland). Additional financial support of the Karl und Veronica Carstens-Stiftung (Essen, Germany) and the Dr. Hauschka Stiftung (Bad Boll/Eckwälden, Germany) is gratefully acknowledged. We had full access to all the data in this study and we take complete responsibility for the integrity of the data and the accuracy of the data analysis.

Conflict of interest: authors declare there is no conflict of interest.

Received: 01 June 2012; Revised: 18 August 2012; Published: 30 September 2012.

Correspondence author: Tim Jäger, tim.jaeger@kikom.ch

How to cite this article: Jäger T, Scherr C, Simon M, Heusser P, Wolf U, Baumgartner S. Comparative study of two bioassays with weakened duckweed and yeast treated with homeopathic preparations. Int J High Dilution Res [online]. 2012 [cited YYYY Month dd]; 11(40):129-130. Proceedings of the XXVI GIRI Symposium; 2012 Sep 20-22; Florence (Italy). GIRI; 2012; Available from: http://www.feg.unesp.br/ ojs/index.php/ijhdr/article/view/574/569 